\title{
EGFR targeted therapy in non-small cell lung cancer: potential role of cetuximab
}

\author{
This article was published in the following Dove Press journal: \\ Biologics: Targets \& Therapy \\ 13 May 2009 \\ Number of times this article has been viewed
}

\author{
Chad A Reade' \\ Apar Kishor Ganti ${ }^{1,2}$ \\ 'Department of Internal Medicine, \\ University of Nebraska Medical \\ Center, Omaha, NE, USA; ${ }^{2}$ Section \\ of Oncology-Hematology, Department \\ of Internal Medicine, VA Medical \\ Center, Omaha, NE, USA
}

\begin{abstract}
Chemotherapy alone has limited ability to significantly improve survival in non-small lung cancer (NSCLC) beyond what has already been achieved. The epidermal growth factor (EGF) pathway plays a vital role in the pathogenesis and progression of NSCLC. Two classes of drugs inhibit the EGF receptor (EGFR) pathway: small molecules that inhibit the intracellular tyrosine kinase activity of the receptor, and monoclonal antibodies that target the extracellular domain in the ligand-binding region. Cetuximab is a human - mouse chimeric immunoglobulin G1 class monoclonal antibody directed against EGFR. Preclinical studies with cetuximab suggested that there was inhibition of growth of human NSCLC cell lines. Cetuximab is currently the focus of intense investigation in various patient populations with NSCLC. This review focuses on clinical trials of cetuximab in NSCLC and identifies future directions with this agent.
\end{abstract}

Keywords: non-small cell lung cancer, EGFR, cetuximab, monoclonal antibodies

\section{Introduction}

Lung cancer is the most common cause of cancer death in both men and women in the United States and around the world. ${ }^{1,2}$ Approximately $85 \%$ of lung cancers are non-small cell lung cancers (NSCLC), and approximately $75 \%$ of these are metastatic at diagnosis. ${ }^{3,4}$ While therapy has evolved over the last few decades and has repeatedly been shown to improve survival, the five-year overall survival of patients with NSCLC is a dismal $15 \%{ }^{2}$. The significant toxicity associated with cytotoxic chemotherapy also excludes a number of patients based on age, co-morbidities, or poor performance status. ${ }^{5}$

Platinum-based doublets have been established therapy for metastatic NSCLC since the mid-1990s. ${ }^{6}$ Numerous studies have shown that, among cytotoxic chemotherapeutics, two-agent therapy is more effective than single-agent therapy. ${ }^{7-9}$ Using three or more cytotoxic therapies does not improve efficacy and increases toxicity. ${ }^{10,11}$ Commonly used chemotherapy doublets incorporate cisplatin or carboplatin with agents that include paclitaxel, docetaxel, vinorelbine, gemcitabine, or more recently pemetrexed. Many regimens given in the first-line setting result in a median survival time of eight to 10 months, with one- and two-year survival rates of $35 \%$ to $45 \%$, and $10 \%$ to $20 \%$, respectively. ${ }^{12}$

While studies with new chemotherapeutic agents are ongoing, evidence now available suggests that chemotherapy alone has limited ability to significantly improve survival beyond what has already been achieved. ${ }^{13}$ Furthermore, toxicities
Correspondence: Apar Kishor Gant

Division of Oncology-Hematology,

University of Nebraska Medical Center,

Omaha, NE 68198-7680, USA

Tel + I 4025596210

Fax +l 4025596520

Email aganti@unmc.edu 
associated with these medicines not only exclude some patients based on poor performance status but also preclude a number of patients from completing chemotherapy courses as scheduled at the full therapeutic dose. ${ }^{5}$ As the knowledge of tumor biology has improved, biologic agents that specifically target molecules thought to be critical to tumorigenesis have emerged. Theoretically, the greater specificity against malignant cells with targeted agents should result in simultaneously greater efficacy and less toxicity, thereby allowing usage in patients previously excluded from consideration of systemic therapy.

Biologic therapies targeting the vascular endothelial growth factor receptor (VEGFR) and the endothelial growth factor receptor (EGFR) are undergoing evaluation to determine their potential role in NSCLC. ${ }^{13}$ Bevacizumab, a monoclonal antibody against VEGFR, ${ }^{14}$ and erlotinib, a small molecule inhibitor of the intracellular tyrosine kinase of EGFR, ${ }^{15}$ currently are indicated for use in NSCLC. Cetuximab, a monoclonal antibody against EGFR, is currently being studied extensively. Here we review the role of cetuximab in the treatment of NSCLC.

\section{EGFR in lung cancer}

EGFR, whose ligands include epidermal growth factor (EGF) and transforming growth factor-alpha (TGF- $\alpha$ ), is a member of the ErbB1 (HER-1) family of receptors. ${ }^{16,17}$ Binding of the extracellular domain by EGF or TGF- $\alpha$ induces dimerization of EGFR, leading directly to activation of kinase activity in the intracellular domain. Receptor tyrosine kinases transfer phosphate groups from bound ATP to tyrosine residues on the carboxy (C) terminal portion of the receptor. ${ }^{18,19}$ Multiple intracellular cascades are activated when adaptor molecules recognize phosphotyrosines on the C-terminal of EGFR: 1. KRAS/RAF/MEK/MAP kinase pathway via binding of Grb2/SOS; 2. PI3-K pathway and the 3. STAT3/5 pathway ${ }^{20}$ (Figure 1). The complexity (ie, pathway overlap and crosstalk) of intracellular signaling via tyrosine kinases is vastly oversimplified by a cursory discussion, but it is evident that activation

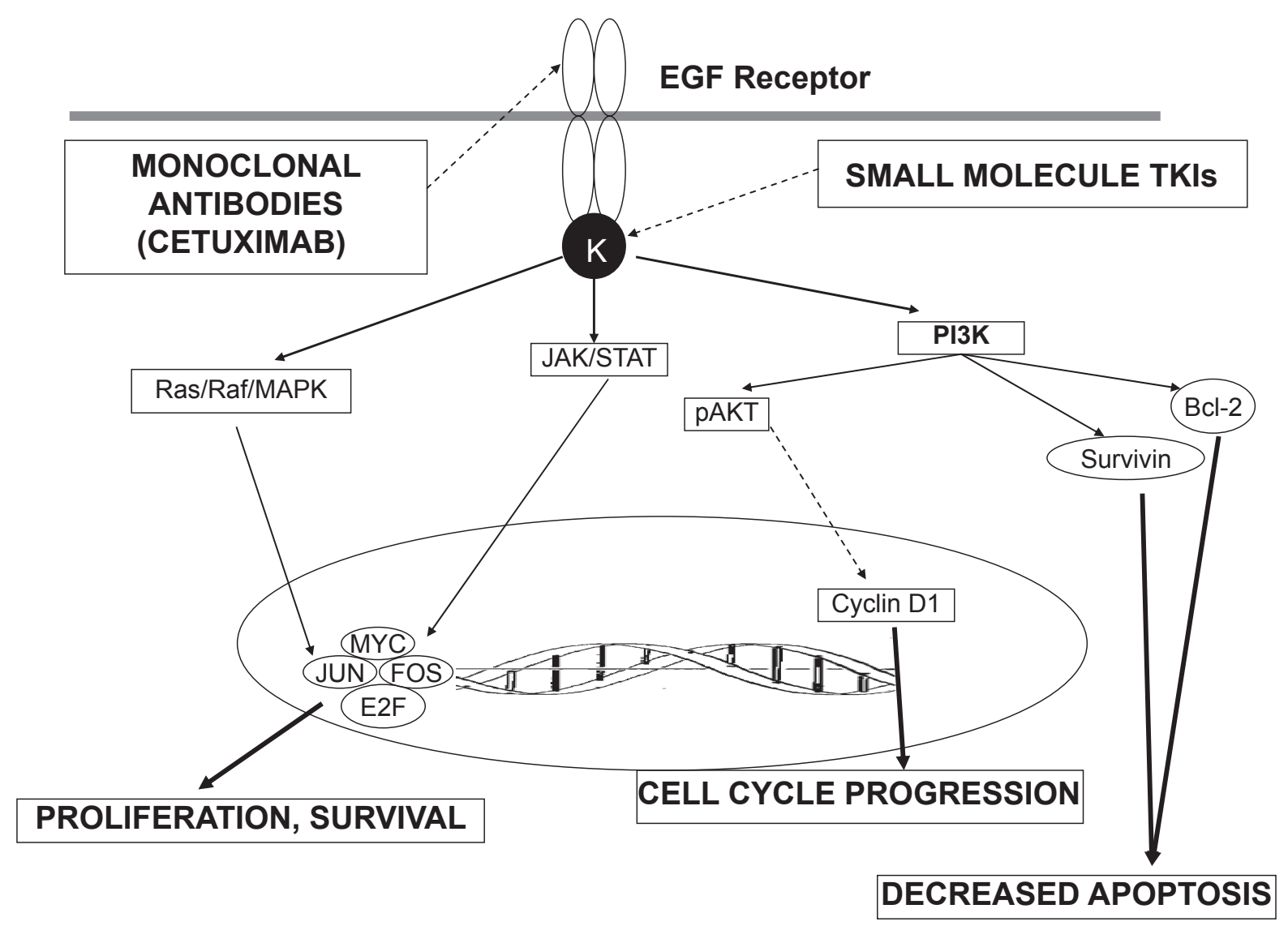

Figure I EGFR signaling pathway. The figure depicts the downstream pathways following activation of the EGF receptor. Binding of a ligand to the receptor activates the tyrosine kinase $(\mathrm{K})$ which then activates the downstream signaling pathways that eventually lead to increased proliferation, cell cycle progression and decreased apoptosis. Solid arrows indicate stimulation, while dashed arrows indicate suppression. Sites of action of the tyrosine kinase inhibitors (TKIs) and monoclonal antibodies are also shown.

Abbreviations: EGFR, endothelial growth factor receptor; PI3K, phosphoinositide-3-kinase; STAT, signal transducer and activator of transcription; JAK, Janus kinase; pAKT, phospho AKT; MAPK, mitogen-activated protein kinase. 
of these pathways serves to increase transcription and cellular proliferation, and inhibit apoptosis. ${ }^{20}$ In malignant cells, they also contribute to angiogenesis and metastasis..$^{21,22}$

The EGF pathway plays a vital role in the pathogenesis and progression of NSCLC. Approximately 50\%-80\% of NSCLC demonstrate overexpression of EGFR activity. ${ }^{23-27}$ Although the majority of NSCLC overexpress EGFR at diagnosis, expression appears to vary with histology (65\% in adenocarcinomas to $84 \%$ in squamous carcinomas). ${ }^{28}$ EGFR expression also seems to correlate with stage at presentation. EGFR levels are higher in pathological stage IV NSCLC than in stage I and II disease and higher in cases with mediastinal involvement than in cases without it. ${ }^{29}$

Although EGFR expression is important in the development and progression of malignancy, its prognostic significance is unclear. Some studies observed a correlation between EGFR expression and tumor invasiveness, ${ }^{30}$ and poorer survival, ${ }^{31-33}$ while there was no relation seen in another study. ${ }^{25}$ EGFR amplification in a subset of patients from the INTACT trials $\mathrm{s}^{34,35}$ appeared to correlate with a response to gefitinib (Iressa ${ }^{\circledR}$; AstraZeneca, Wilmington, DE); but no effect on overall survival was seen. ${ }^{36}$ In a metaanalysis of 2792 patients enrolled in 18 different studies, Nakamura and colleagues found that EGFR overexpression had no impact on survival in patients with NSCLC (hazard ratio [HR], 1.14; 95\% confidence interval [CI]: 0.97-1.34; $\mathrm{p}=0.1) .{ }^{37}$ Other studies however found that not only is EGFR expression increased in NSCLC, but its presence is associated with poor prognosis. ${ }^{30-32,38}$

Various mechanisms for upregulation of receptor activity in NSCLC have been discovered:

- Increased production of EGFR with or without increased EGFR gene copy number ${ }^{39}$

- EGFR mutations resulting in constitutive activation of the receptor, regardless of ligand binding 39,40

- Increased production of ligands, TGF- $\alpha$, or EGF or related proteins. ${ }^{24}$

The most common clinically relevant assays for EGFR expression in NSCLC include assays for gene amplification, ${ }^{41}$ immunohistochemical (IHC) stains for protein overexpression, ${ }^{42}$ and detection of specific mutations by DNA sequencing. ${ }^{43}$ EGFR copy number can be measured using fluorescence in situ hybridization (FISH), ${ }^{44}$ while EGFR mutations can be detected using sequencing analyses of DNA. ${ }^{45}$

\section{Targeted agents against EGFR}

Two classes of drugs inhibiting the EGFR pathway are currently in clinical usage: small molecules that inhibit the intracellular tyrosine kinase activity of the receptor, and monoclonal antibodies that target the extracellular domain in the ligand-binding region. Gefitinib (Iressa ${ }^{\circledR}$; AstraZeneca) and Erlotinib (Tarceva ${ }^{\circledR}$; OSI Pharmaceuticals, Inc. Melville, NY) are the two most studied drugs in the EGFR-tyrosine kinase inhibitor class. Canertinib (C11033), lapatinib (GW572016, Tykerb ${ }^{\circledR}$; GlaxoSmithKline, Research Triangle Park, NC), PKI166, and EKB569 are examples of other drugs in this class currently in development. The most well known EGFR monoclonal antibody is cetuximab (Erbitux ${ }^{\circledR}$; BristolMyers Squibb Company, Princeton, NJ). Panitumumab (AMG706, Vectibix ${ }^{\circledR}$; Amgen Inc., Thousand Oaks, CA), matuzumab (EMD7000), and nimotuzumab (h-R3) are EGFR monoclonal antibodies currently being developed.

\section{Clinical trials of tyrosine kinase inhibitors \\ Gefitinib}

Gefitinib was the first EGFR-TKI tested in clinical trials. Two phase II trials (IDEAL-1 and IDEAL-2) showed that gefitinib produced a response rate of $9 \%-18 \%$ and overall disease control rate of $43 \%-50 \%$ in patients with relapsed NSCLC. ${ }^{46,47}$ However the phase III ISEL trial that randomized nearly 1700 patients with advanced NSCLC to gefitinib or placebo, failed to reveal an overall survival benefit. ${ }^{48}$ A recent phase III trial (INTEREST) showed that gefitinib was noninferior to docetaxel in terms of overall survival (OS) in patients with relapsed NSCLC; it was also better tolerated and correlated with better quality of life. ${ }^{49}$ Similarly, another randomized phase II study comparing gefitinib with vinorelbine in chemo-naïve elderly patients with advanced non-small-cell lung cancer found that gefitinib had similar response rates and progression-free (PFS) and overall survival to vinorelbine. ${ }^{50}$

Two trials (INTACT-1 and INTACT-2) trials that combined gefitinib with chemotherapy in the first-line setting, ${ }^{34,35}$ did not show any survival benefit from the addition of gefitinib. On the other hand, although the IPASS (Iressa Pan-Asia Study) comparing gefitinib with carboplatin/paclitaxel for previously untreated Asian never- or light-smokers with advanced adenocarcinoma found no difference in overall survival, ${ }^{51}$ patients who had $E G F R$ gene mutations had a greater response rate $(71.2 \%$ vs $41.3 \%)$ and improved overall survival (HR, 0.48; 95\% CI: 0.36-0.64; $\mathrm{p}<0.0001)$ with gefitinib.

\section{Erlotinib}

Unlike gefitinib, erlotinib has shown clinical efficacy that has resulted in its unrestricted US Food and Drug Administration 
(FDA) approval in NSCLC. BR21, a randomized phase III trial of 731 patients with stage IIIB or IV NSCLC showed that patients randomized to erlotinib had a statistically significant increase in overall survival, PFS, and overall response rate. ${ }^{15}$ However, similar to the results seen with gefitinib, phase III trials evaluating the combination of a platinumbased doublet alone or with erlotinib, gemcitabine - cisplatin $(\text { TALENT) })^{52}$ and carboplatin - paclitaxel (TRIBUTE) $)^{53}$ did not show any advantage to the addition of erlotinib.

\section{Cetuximab}

\section{Introduction}

Cetuximab is a human-mouse chimeric immunoglobulin G1 (IgG1) class monoclonal antibody directed against the EGFR with proven second- or third-line efficacy in colorectal $^{54}$ and head and neck cancers. ${ }^{55,56}$ This monoclonal antibody binds to the extracellular ligand-binding domain with affinity five times greater than natural ligands like TGF- $\alpha$ and EGF. ${ }^{57}$ Binding of cetuximab prevents dimerization and subsequent activation by auto-phosphorylation of the receptor in the intracellular kinase domain. ${ }^{58}$ The receptor-antibody complex is internalized and degraded, thereby decreasing EGFR availability. ${ }^{59}$ In vitro studies show the antibody also mediates antibody-dependent cellular cytotoxicity (ADCC) against the receptor. ${ }^{60}$

Preclinical studies with cetuximab suggested that there was inhibition of growth of human NSCLC cell lines and other EGFR-expressing cell lines in vitro ${ }^{61-63}$ and in athymic nude mice, ${ }^{61,63}$ and combinations with cytotoxic agents produced synergistic greater delay of tumor growth. ${ }^{63,64}$ In addition, cetuximab had a potentiating effect on the growth delay produced by radiotherapy. ${ }^{65}$

Doody and colleagues studied the activity of cetuximab with NSCLC lines bearing both wild-type EGFR and those with activating mutations in the intracellular kinase domain: not only those known to confer sensitivity to gefitinib and erlotinib (L858R and delL747-T753insS) but also the TKI-resistant mutation T790M. ${ }^{66}$ They found that ligand-independent phosphorylation of the T790M lines was unaffected by cetuximab (as measured by assays for phosphorylated EGFR, and downstream phosphorylated molecules Akt and MAPK) and cellular proliferation was inhibited. Previous studies had shown that binding of EGFR antibodies to wild-type EGFR resulted in increased internalization and degradation of the receptor-antibody complex without stimulating phosphorylation of the receptor. ${ }^{67}$ Similarly, Doody and colleagues demonstrated that mutant EGFR (including
T790M) was internalized and degraded at a higher rate than wild-type EGFR. ${ }^{66}$

\section{Clinical trials}

Given the promising results of these preclinical experiments, cetuximab was introduced into clinical trials. While cetuximab was generally well tolerated, the common side effects seen in phase I testing included: skin toxicity, nausea, fever/ chills, asthenia, and elevation of transaminases; grade 3 or 4 toxicities included dyspnea, aseptic meningitis, anaphylactoid reaction, diarrhea, and epiglottitis. ${ }^{68}$

\section{First-line therapy}

A phase I/II trial combining cetuximab with paclitaxel/ carboplatin produced $65 \%$ overall disease control rate (partial response [PR], 26\%; stable disease, 39\%). ${ }^{69}$ Median PFS, OS, and one-year survival were 5 months, 11 months, and $40 \%$, respectively. Similar results were seen when cetuximab was combined with gemcitabine and carboplatin (PR 28\%; stable disease, 60\%; median PFS, 5.3 months; median OS, 10.3 months; one-year survival, 45\%). ${ }^{70}$ A randomized phase II study comparing vinorelbine/cisplatin with the same chemotherapy plus cetuximab ${ }^{71}$ suggested that addition of cetuximab led to better outcomes (odds ratio [OR], 35\% vs 28\%; median PFS, 5.0 vs 4.6 months; median OS, 8.3 vs 7.3). Similar results were seen in another randomized phase II study of gemcitabine plus cisplatin or carboplatin with or without cetuximab. Although the study design was noncomparative, addition of cetuximab seemed to improve outcomes in terms of PR (27.7\% vs $18.2 \%)$, median PFS (5.1 vs 4.2 months), and median OS (11.99 vs 9.26 months). ${ }^{72}$

The results of these trials led to the conduct of the phase III FLEX trial, ${ }^{73}$ which randomized 1125 patients with EGFR overexpressing advanced NSCLC to cisplatin/vinorelbine with or without cetuximab. The basis for patient selection in this trial was presence of the EGFR staining by IHC, which the investigators defined as the presence of at least one EGFR-positive cell. This is the first study that has used IHC to determine eligibility for EGFR-targeted therapy.

Addition of cetuximab led to a significant improvement in overall survival (11.3 vs 10.1 months; HR, 0.871; $P=0.0441)$. One-year survival also was higher in the cetuximab group (47\% vs 42\%). Interestingly however there was no difference in PFS between the two groups. Though the benefit with the addition of cetuximab was modest, the results of this trial led to cetuximab being incorporated into the National Comprehensive Cancer Network (USA) guidelines for use in the first-line setting in combination with cisplatin 
and vinorelbine (see http://www.nccn.org/professionals/ physician_gls/PDF/nscl.pdf).

Preliminary results of pre-specified subgroup analyses suggest a greater benefit with the addition of cetuximab in Caucasians. Caucasian patients who received cetuximab had a median survival of 10.5 months as opposed to 9.1 months in those who did not receive cetuximab (HR, 0.8; $P=0.0025)$. However although Asians had a better prognosis in general, there was no additional benefit to the addition of cetuximab. Median survival in the cetuximab group among Asians was 17.6 months as compared to 20.4 months in the placebo group (HR, 1.179; $P=0.4992$ ).

\section{Second-line therapy}

Single agent cetuximab seems to result in outcomes similar to docetaxel, pemetrexed or erlotinib in patients with recurrent or progressive NSCLC, ${ }^{74}$ all of which are currently approved for the treatment of patients with NSCLC, who have failed first-line therapy. In this study by Hanna and colleagues, although the response rate was only $4.5 \%$ (3/66), 30.3\% of patients had stable disease. Moreover, median time to progression and median OS were 2.3 and 8.9 months, respectively, and one-year survival was $43.9 \%$, values numerically similar to those seen in studies with erlotinib, pemetrexed, and docetaxel. In the second-line setting, cetuximab was combined with docetaxe ${ }^{75}$ and demonstrated a response rate of $25 \%$ among 20 patients with minimal toxicities.

\section{Combination with chemoradiotherapy}

Positive results for the radio-sensitizing effects of cetuximab in head and neck cancer ${ }^{55}$ led investigators to test cetuximab in combination with synchronous radiotherapy following induction chemotherapy in chemotherapy-naïve stage III NSCLC patients. ${ }^{76}$ The toxicity results published thus far suggest that this is a safe regimen. The Cancer and Leukemia Group B (CALGB) conducted a randomized phase II study of thoracic radiation (70 Gy) along with carboplatin and pemetrexed for four cycles (arm A) or the same chemotherapy regimen along with cetuximab for additional six weeks (arm B). Subsequently all patients received four additional cycles of pemetrexed as consolidation therapy. The main adverse effects were hematologic with grades $3 / 4$ neutropenia seen in $36 \%$ and $37 \%$ patients in arms $\mathrm{A}$ and $\mathrm{B}$ respectively and grades $3 / 4$ thrombocytopenia in $30 \%$ and $34 \%$ of patients. Esophagitis (35\% and $22 \%$ ), fatigue (22\% and $18 \%$ ) and skin rash $(3 \%$ and $22 \%)$ were the most common nonhematologic toxicities. These initial results suggest acceptable tolerability. Efficacy results of this study are awaited.
Currently, multiple studies are currently underway evaluating the role of cetuximab in different patient populations with NSCLC (Table 1). The results of these studies should help us understand the exact role of cetuximab in the treatment of NSCLC.

\section{Targeting EGFR inhibitors}

One of the major issues in the use of EGFR-targeted therapy in NSCLC has been the identification of patients who would actually benefit from these agents. Identifying predictive markers for a response to the EGFR-targeted therapy has been quite challenging. Most of the available information focuses on response to EGFR TKIs rather than cetuximab, since these agents have been in use for a longer period of time.

Clinical factors that can help predict response to EGFR TKIs have been investigated. A subset analysis of the BR21 trial showed that women, nonsmokers, patients with adenocarcinoma and patients with Asian ethnicity had better outcomes with erlotinib. ${ }^{15}$ A subset analysis of the IDEAL-1 trial ${ }^{47}$ revealed that patients with adenocarcinoma had superior outcomes, despite the observation that high EGFR expression is more common in squamous cell carcinomas than in adenocarcinomas. ${ }^{77}$ Mutation studies of the EGFR gene showed that somatic mutations in the tyrosine kinase domain of the EGFR gene predicted for response to gefitinib and were associated with an improved outcome. ${ }^{36,78-80}$

Correlative studies from the ISEL trial showed that a high EGFR gene copy number was a predictor of clinical benefit from gefitinib. ${ }^{81}$ Patients whose tumors expressed the EGFR protein and who were treated with gefitinib had a slightly greater survival advantage (HR, 0.77; $95 \%$ CI: 0.56-1.08; $P=0.126)$. Also, patients with $E G F R$ mutations had higher response rates than patients without EGFR mutations (37.5\% vs 2.6\%). In another analysis of 204 patients treated with gefitinib, Hirsch and colleagues found that although increased EGFR and HER2 gene copy number, EGFR protein overexpression, EGFR mutations, and pAKT overexpression were all associated with significantly higher response rates only increased EGFR gene copy number and EGFR protein overexpression correlated with improved survival. ${ }^{82}$ In similar studies on samples from patients treated with erlotinib, there was no association between the presence of EGFR mutations and responsiveness to erlotinib. However similar to the findings of Hirsch and colleagues, in this analysis, expression of EGFR and an increased number of copies of EGFR were associated with responsiveness to erlotinib but not with increased survival. ${ }^{83}$ 
Table I Current or planned trials of cetuximab in non-small cell lung cancer

\begin{tabular}{|c|c|c|c|}
\hline Name/ID & Population & Phase & Interventions \\
\hline NCT00II 2294 & $\begin{array}{l}\text { Advanced or metastatic, } \\
\text { chemotherapy naïe }\end{array}$ & III & Taxane + carboplatin \pm cetuximab \\
\hline NCT000972I4 & Stage IIIB/IV & II & Carboplatin + cetuximab \\
\hline NCT00097227 & Stage IIIB/IV & II & Carboplatin + paclitaxel + cetuximab \\
\hline NCT00II 2346 & Stage IIIB/IV & II & Gemcitabine + platinum \pm cetuximab \\
\hline NCT00II8I83 & Stage IIIB/IV & ॥ & Docetaxel + cetuximab or bortezomib \\
\hline NCT00368992 & Stage IIIB/IV & II & $\begin{array}{l}\text { Cetuximab + paclitaxel + carboplatin + bevacizumab; } \\
\text { maintenance cetuximab + bevacizumab }\end{array}$ \\
\hline NCT0034329I & $\begin{array}{l}\text { Stage IIIB/IV or recurrent } \\
\text { chemotherapy naïve }\end{array}$ & II & $\begin{array}{l}\text { Cetuximab + paclitaxel + carboplatin + bevacizumab; } \\
\text { maintenance cetuximab + bevacizumab }\end{array}$ \\
\hline NCT00027755 & Treatment naïve stage IV & $\mathrm{lb} / \mathrm{lla}$ & Cetuximab + gemcitabine + carboplatin \\
\hline NCT00I93453 & Unresectable stage III/IV & II & Cetuximab + gemcitabine + docetaxel \\
\hline CALC-I & Advanced & II & Cetuximab + gemcitabine \\
\hline NCT0025I498 & Advanced & II & Carboplatin + docetaxel + cetuximab \\
\hline NCT003I5I85 & Advanced & II & Cetuximab \\
\hline NCT00408499 & Advanced & II & Erlotinib + cetuximab \\
\hline NCT0056I054 & Advanced & II & Cetuximab + cisplatin + gemcitabine \\
\hline NCT0082884I & Advanced & II & $\begin{array}{l}\text { Cetuximab + either carboplatin }+ \text { paclitaxel or } \\
\text { platinum }+ \text { gemcitabine/pemetrexed }\end{array}$ \\
\hline NCT008427I2 & Advanced & II & $\begin{array}{l}\text { Cilengitide }+ \text { cetuximab }+ \text { platinum-based } \\
\text { chemotherapy }\end{array}$ \\
\hline NCT00I65334 & Elderly, treatment naïve, advanced & II & Vinorelbine + cetuximab \\
\hline NCT00673738 & Locally advanced, poor PS, elderly & II & Cetuximab + conformal thoracic radiotherapy \\
\hline NCT00820755 & Maintenance & II & $\begin{array}{l}\text { Cetuximab maintenance following platinum-based } \\
\text { therapy }\end{array}$ \\
\hline NCT007I6456 & $\begin{array}{l}\text { Adenocarcinoma with acquired } \\
\text { resistance to erlotinib }\end{array}$ & II & Erlotinib + cetuximab \\
\hline NCT00694603 & Progression on TKI & II & Cetuximab \\
\hline NCT00063388 & Recurrent & II & Cetuximab \\
\hline NCT00I03207 & Recurrent & II & Cetuximab \\
\hline NCT00I623I8 & Recurrent & I & Gefitinib + cetuximab \\
\hline NCT002I6203 & Recurrent & $\mathrm{I} / \mathrm{II}$ & Pemetrexed + cetuximab \\
\hline NCT00095I99 & Recurrent/progressive & III & Docetaxel vs cetuximab \\
\hline NCT00II8II8 & Recurrent/progressive & II & Cetuximab \\
\hline NCT0020393I & Recurrent/progressive & II & Cetuximab or cetuximab + pemetrexed \\
\hline NCT005I983। & Second-line & II & Vinflunine + cetuximab \\
\hline NCT00II55I8 & Stage III & II & Cetuximab + radiation \\
\hline NCT00I246I8 & Stage III & II & Cetuximab + radiation \\
\hline NCT00288054 & Stage III & I & Docetaxel + cetuximab + radiation \\
\hline NCT00522886 & Stage III & I & $\begin{array}{l}\text { Carboplatin }+ \text { gemcitabine followed by cetuximab }+ \\
\text { radiation }+ \text { cisplatin }+ \text { vinorelbine }\end{array}$ \\
\hline NCT00533949 & Stage III & II & $\begin{array}{l}\text { Carboplatin }+ \text { paclitaxel } \pm \text { cetuximab }+ \text { either } \\
\text { standard or high-dose radiation }\end{array}$ \\
\hline NCT0008I302 & Stage IIIA & II & Carboplatin + paclitaxel + cetuximab + radiation \\
\hline NCT00492206 & Stage IIIA/IIIB & II & $\begin{array}{l}\text { Cetuximab + radiation followed by consolidation } \\
\text { chemotherapy }\end{array}$ \\
\hline
\end{tabular}


Three retrospective studies from Japan and Korea, where the somatic EGFR mutations are detected approximately thrice as common than in the United States and Europe have shown that response rates following treatment with gefitinib in patients with $E G F R$ mutations ranged from $65 \%-83 \%$ as compared to $10 \%-15 \%$ for those without the mutations. ${ }^{84-86}$ This translated into an overall survival advantage for treatment with gefitinib in patients with the mutations.

Hirsch and colleagues analyzed tissue samples from patients enrolled onto a phase II trial of paclitaxel/carboplatin with either sequential (cetuximab weekly for one year following the completion of chemotherapy) or concurrent (weekly cetuximab during and for one year following chemotherapy) cetuximab therapy for EGFR status. ${ }^{87}$ Progression free survival and disease control rate (DCR) were statistically significantly better in FISH (+) patients, and there was a nonsignificant trend toward higher objective response rate (ORR) as compared to FISH (-) patients in both arms. The authors concluded that EGFR FISH status is a predictive factor for selection of NSCLC patients for cetuximab plus chemotherapy. Critics point out many potential flaws in attempting to draw conclusions based on these results and urge caution in interpreting them. ${ }^{88}$

Although EGFR-targeted therapies have been approved for use without molecular testing, immunohistochemistry to detect EGFR protein overexpression, fluorescence in situ hybridization to detect $E G F R$ gene amplification, and mutational analyses of the $E G F R$ gene have all been proposed as candidates to help predict benefit from EGFR-directed therapy in NSCLC. In fact the FLEX trial was the first to incorporate the presence of EGFR positivity as an inclusion criterion for the study ${ }^{73}$ However even in this trial, a rather loose definition of EGFR positivity was employed; patients who had even one cell staining for EGFR by IHC were considered EGFR positive.

As is evident from the disparity in the results from the studies discussed above, there is an urgent need for standardization of these assays. Without such standardization, routine utilization of these technologies to guide clinical decision making in a given patient will be difficult. In order to address this issue the Molecular Assays in NSCLC Working Group was convened under the sponsorship of Genentech Inc, Roche Pharmaceuticals, and OSI Pharmaceuticals, Inc, to evaluate the available molecular assays for use in the clinical trial setting and provide recommendations for application and interpretation of these tests. ${ }^{89}$ The recommendations from this group included the following:

- At least three representative areas should be assessed per tumor section.
- The minimum cell number to be evaluated should be: FISH: $>100$ assessable tumor cell nuclei, IHC/mutation: 2,000 cells, Direct sequencing $-50 \%-70 \%$ tumor cells.

- Standardization of molecular assays:

- Kit-based antibodies preferred for immunohistochemistry, with a simple standard scoring system needed.

- FISH: Two-color FISH with CEP ${ }^{\circledR}$ control, using the Colorado scoring system..$^{90}$

- Mutational analysis: Direct sequencing; replicate PCR and sequencing reactions to establish mutation status of each sample amplicon.

The tumor biology of NSCLC prevents easy answers. Unlike CML that relies almost exclusively on the tyrosine kinase activated by the fusion Bcr-Abl, ${ }^{91}$ or a closer analogy, the overexpression of HER-2 in $25 \%-30 \%$ of breast cancers, ${ }^{92}$ carcinogenesis of NSCLC is not so heavily dependant on EGFR status (by any measure of EGFR). The absence of this "oncogene addiction"93 in NSCLC illustrates why patients with NSCLC will continue to require multimodal therapy for the foreseeable future.

\section{Future directions}

It is likely that the lessons on how to use cetuximab wisely may come from experience in patients with colon cancer. RAS is one of the downstream signaling molecules stimulated by active EGFR. Mutations that cause constitutive activation of the K-RAS oncogene predict resistance to cetuximab in colorectal cancer (CRC) cell lines. ${ }^{94}$ This study emerged in the wake of retrospective observations that patients who failed to respond to cetuximab were more likely to have mutated, constitutively activated K-RAS, ${ }^{95,96}$ although some studies observe good clinical response in patients with mutated K-RAS. ${ }^{97}$ A recently published study noted a mutation in the extracellular domain (R521K of exon 13) of EGFR that predicted response to cetuximab. ${ }^{97}$

However these observations must be made with the caveat in mind that tumor biology of colon cancer is different from NSCLC. Somatic mutations in EGFR are almost never seen in CRC cell lines. ${ }^{98}$ Also cetuximab activity in colorectal cancer does not correlate with EGFR protein levels as measured by $\mathrm{IHC}^{54,99}$ but does correlate with gene copy number measured by FISH. ${ }^{100}$ Despite this, multiple trials in NSCLC have shown that mutant K-RAS predicts resistance to erlotinib. ${ }^{101,102}$

Future investigations should stratify patients with respect to EGFR status and other potential predictive factors like K-RAS mutations. Future studies should address the predictive markers for cetuximab activity, be it gene amplification by FISH or protein overexpression by IHC or mutation analysis. 
Also studies should be conducted to determine if cetuximab is useful in patients who have already failed an EGFR-TKI.

\section{Disclosure}

The authors report no conflicts of interest in this work.

\section{References}

1. Parkin DM. Global cancer statistics in the year 2000. Lancet Oncol. 2001;2(9):533-543.

2. Jemal A, Siegel R, Ward E, et al. Cancer statistics, 2008. CA Cancer J Clin. 2008;58(2):71-96.

3. Yang P, Allen MS, Aubry MC, et al. Clinical features of 5,628 primary lung cancer patients: experience at Mayo Clinic from 1997 to 2003. Chest. 2005;128(1):452-462.

4. Govindan R, Page N, Morgensztern D, et al. Changing epidemiology of small-cell lung cancer in the United States over the last 30 years: analysis of the surveillance, epidemiologic, and end results database. J Clin Oncol. 2006;24(28):4539-4544.

5. Avery EJ, Kessinger A, Ganti AK. Therapeutic options for elderly patients with advanced non-small cell lung cancer. Cancer Treat Rev. 2009. Jan 18. [Epub ahead of print].

6. Souquet PJ, Chauvin F, Boissel JP, Bernard JP. Meta-analysis of randomised trials of systemic chemotherapy versus supportive treatment in non-resectable non-small cell lung cancer. Lung Cancer. 1995; 12(Suppl 1):S147-S154.

7. Sandler AB, Nemunaitis J, Denham C, et al. Phase III trial of gemcitabine plus cisplatin versus cisplatin alone in patients with locally advanced or metastatic non-small-cell lung cancer. J Clin Oncol. 2000; 18(1):122-130.

8. Wozniak AJ, Crowley JJ, Balcerzak SP, et al. Randomized trial comparing cisplatin with cisplatin plus vinorelbine in the treatment of advanced non-small-cell lung cancer: a Southwest Oncology Group study. J Clin Oncol. 1998;16(7):2459-2465.

9. Gatzemeier U, von Pawel J, Gottfried M, et al. Phase III comparative study of high-dose cisplatin versus a combination of paclitaxel and cisplatin in patients with advanced non-small-cell lung cancer. J Clin Oncol. 2000;18(19):3390-3399.

10. Azim HA Jr, Elattar I, Loberiza FR Jr, et al. Third generation triplet cytotoxic chemotherapy in advanced non-small cell lung cancer: A systematic overview. Lung Cancer. 2000;64(2):194-198.

11. Delbaldo C, Michiels S, Syz N, et al. Benefits of adding a drug to a single-agent or a 2-agent chemotherapy regimen in advanced nonsmall-cell lung cancer: a meta-analysis. JAMA. 2004;292(4):470-484.

12. Schiller JH, Harrington D, Belani CP, et al. Comparison of four chemotherapy regimens for advanced non-small-cell lung cancer. $N$ Engl $J$ Med. 2002;346(2):92-98.

13. Azim HA Jr, Ganti AK. Targeted therapy in advanced non-small cell lung cancer (NSCLC): where do we stand? Cancer Treat Rev. 2006; 32(8):630-636.

14. Sandler A, Gray R, Perry MC, et al. Paclitaxel-carboplatin alone or with bevacizumab for non-small-cell lung cancer. N Engl J Med. 2006; 355(24):2542-2550.

15. Shepherd FA, Rodrigues Pereira J, Ciuleanu T, et al. Erlotinib in previously treated non-small-cell lung cancer. N Engl J Med. 2005;353(2):123-132.

16. Carpenter G, Cohen S. Epidermal growth factor. J Biol Chem. 1990; 265(14):7709-7712.

17. Wells A. EGF receptor. Int J Biochem Cell Biol. 1999;31(6):637-643.

18. Klapper LN, Kirschbaum MH, Sela M, Yarden Y. Biochemical and clinical implications of the ErbB/HER signaling network of growth factor receptors. Adv Cancer Res. 2000;77:25-79.

19. Honegger AM, Kris RM, Ullrich A, Schlessinger J. Evidence that autophosphorylation of solubilized receptors for epidermal growth factor is mediated by intermolecular cross-phosphorylation. Proc Natl Acad Sci U S A. 1989;86(3):925-929.
20. Jorissen RN, Walker F, Pouliot N, et al. Epidermal growth factor receptor: mechanisms of activation and signalling. Exp Cell Res. 2003; 284(1):31-53.

21. Huang SM, Harari PM. Epidermal growth factor receptor inhibition in cancer therapy: biology, rationale and preliminary clinical results. Invest New Drugs. 1999;17(3):259-269.

22. Baselga J, Albanell J. Targeting epidermal growth factor receptor in lung cancer. Curr Oncol Rep. 2002;4(4):317-324.

23. Sobol RE, Astarita RW, Hofeditz C, et al. Epidermal growth factor receptor expression in human lung carcinomas defined by a monoclonal antibody. J Natl Cancer Inst. 1987;79(3):403-407.

24. Salomon DS, Brandt R, Ciardiello F, Normanno N. Epidermal growth factor-related peptides and their receptors in human malignancies. Crit Rev Oncol Hematol. 1995;19(3):183-232.

25. Rusch V, Klimstra D, Venkatraman E, et al. Overexpression of the epidermal growth factor receptor and its ligand transforming growth factor alpha is frequent in resectable non-small cell lung cancer but does not predict tumor progression. Clin Cancer Res. 1997;3(4):515-522.

26. Ritter CA, Arteaga CL. The epidermal growth factor receptor-tyrosine kinase: a promising therapeutic target in solid tumors. Semin Oncol. 2003;30(1 Suppl 1):3-11.

27. Fontanini G, De Laurentiis M, Vignati S, et al. Evaluation of epidermal growth factor-related growth factors and receptors and of neoangiogenesis in completely resected stage I-IIIA non-small-cell lung cancer: amphiregulin and microvessel count are independent prognostic indicators of survival. Clin Cancer Res. 1998;4(1):241-249.

28. Bunn PA, Jr., Franklin W. Epidermal growth factor receptor expression, signal pathway, and inhibitors in non-small cell lung cancer. Semin Oncol. 2002;29(5 Suppl 14):38-44.

29. Fujino S, Enokibori T, Tezuka N, et al. A comparison of epidermal growth factor receptor levels and other prognostic parameters in nonsmall cell lung cancer. Eur J Cancer. 1996;32A(12):2070-2074.

30. Pavelic K, Banjac Z, Pavelic J, Spaventi S. Evidence for a role of EGF receptor in the progression of human lung carcinoma. Anticancer Res. 1993;13(4):1133-1137.

31. Veale D, Kerr N, Gibson GJ, Kelly PJ, Harris AL. The relationship of quantitative epidermal growth factor receptor expression in nonsmall cell lung cancer to long term survival. Br J Cancer. 1993;68(1): $162-165$.

32. Volm M, Rittgen W, Drings P. Prognostic value of ERBB-1, VEGF, cyclin A, FOS, JUN and MYC in patients with squamous cell lung carcinomas. Br J Cancer. 1998;77(4):663-669.

33. Brabender J, Danenberg KD, Metzger R, et al. Epidermal growth factor receptor and HER2-neu mRNA expression in non-small cell lung cancer Is correlated with survival. Clin Cancer Res. 2001;7(7):1850-1855.

34. Herbst RS, Giaccone G, Schiller JH, et al. Gefitinib in combination with paclitaxel and carboplatin in advanced non-small-cell lung cancer: a phase III trial - INTACT 2. J Clin Oncol. 2004;22(5):785-794.

35. Giaccone G, Herbst RS, Manegold C, et al. Gefitinib in combination with gemcitabine and cisplatin in advanced non-small-cell lung cancer: a phase III trial - INTACT 1. J Clin Oncol. 2004;22(5):777-784.

36. Bell DW, Lynch TJ, Haserlat SM, et al. Epidermal growth factor receptor mutations and gene amplification in non-small-cell lung cancer: molecular analysis of the IDEAL/INTACT gefitinib trials. J Clin Oncol. 2005;23(31):8081-8092.

37. Nakamura H, Kawasaki N, Taguchi M, Kabasawa K. Survival impact of epidermal growth factor receptor overexpression in patients with non-small cell lung cancer: a meta-analysis. Thorax. 2006;61(2): $140-145$.

38. Rusch V, Baselga J, Cordon-Cardo C, et al. Differential expression of the epidermal growth factor receptor and its ligands in primary non-small cell lung cancers and adjacent benign lung. Cancer Res. 1993;53(10 Suppl):2379-2385.

39. Hirsch FR, Varella-Garcia M, Bunn PA Jr, et al. Epidermal growth factor receptor in non-small-cell lung carcinomas: correlation between gene copy number and protein expression and impact on prognosis. J Clin Oncol. 2003;21(20):3798-3807. 
40. Moscatello DK, Holgado-Madruga M, Godwin AK, et al. Frequent expression of a mutant epidermal growth factor receptor in multiple human tumors. Cancer Res. 1995;55(23):5536-5539.

41. Hirsch FR, Varella-Garcia M, Bunn PA Jr, et al. Epidermal growth factor receptor in non-small-cell lung carcinomas: correlation between gene copy number and protein expression and impact on prognosis. J Clin Oncol. 2003;21(20):3798-3807.

42. Selvaggi G, Novello S, Torri V, et al. Epidermal growth factor receptor overexpression correlates with a poor prognosis in completely resected non-small-cell lung cancer. Ann Oncol. 2004;15(1):28-32.

43. Pao W, Miller V, Zakowski M, et al. EGF receptor gene mutations are common in lung cancers from "never smokers" and are associated with sensitivity of tumors to gefitinib and erlotinib. Proc Natl Acad Sci US A. 2004;101(36):13306-13311.

44. Cappuzzo F, Hirsch FR, Rossi E, et al. Epidermal growth factor receptor gene and protein and gefitinib sensitivity in non-small-cell lung cancer. J Natl Cancer Inst. 2005;97(9):643-655.

45. von Eyben FE. Epidermal growth factor receptor inhibition and nonsmall cell lung cancer. Crit Rev Clin Lab Sci. 2006;43(4):291-323.

46. Fukuoka M, Yano S, Giaccone G, et al. Multi-institutional randomized phase II trial of gefitinib for previously treated patients with advanced non-small-cell lung cancer (The IDEAL 1 Trial) [corrected]. J Clin Oncol. 2003;21(12):2237-2246.

47. Kris MG, Natale RB, Herbst RS, et al. Efficacy of gefitinib, an inhibitor of the epidermal growth factor receptor tyrosine kinase, in symptomatic patients with non-small cell lung cancer: a randomized trial. JAMA. 2003;290(16):2149-2158.

48. Thatcher N, Chang A, Parikh P, et al. Gefitinib plus best supportive care in previously treated patients with refractory advanced nonsmall-cell lung cancer: results from a randomised, placebo-controlled, multicentre study (Iressa Survival Evaluation in Lung Cancer). Lancet. 2005;366(9496):1527-1537.

49. Douillard JY, Kim E, Hirsh V, et al. Gefitinib (IRESSA) versus docetaxel in patients with locally advanced or metastatic non-smallcell lung cancer pre-treated with platinum-based chemotherapy: a randomized, open-label Phase III study (INTEREST). J Thoracic Oncol. 2007;2(8 Suppl 4):S305-S306.

50. Crino L, Cappuzzo F, Zatloukal P, et al. Gefitinib versus vinorelbine in chemotherapy-naive elderly patients with advanced non-small-cell lung cancer (INVITE): a randomized, phase II study. J Clin Oncol. 2008;26(26):4253-4260.

51. Mok T, Wu Y-L, Thongprasert S, et al. Phase III, randomised, openlabel, first-line study of gefitinib $(\mathrm{G})$ vs carboplatin/paclitaxel (C/P) in clinically selected patients (pts) with advanced non-small-cell lung cancer (NSCLC) (IPASS). Ann Oncol. 2008;19(Suppl 8):viii1-viii4.

52. Gatzemeier U, Pluzanska A, Szczesna A, et al. Phase III study of erlotinib in combination with cisplatin and gemcitabine in advanced non-small-cell lung cancer: the Tarceva Lung Cancer Investigation Trial. J Clin Oncol. 2007;25(12):1545-1552.

53. Herbst RS, Prager D, Hermann R, et al. TRIBUTE: a phase III trial of erlotinib hydrochloride (OSI-774) combined with carboplatin and paclitaxel chemotherapy in advanced non-small-cell lung cancer. J Clin Oncol. 2005;23(25):5892-5899.

54. Cunningham D, Humblet Y, Siena S, et al. Cetuximab monotherapy and cetuximab plus irinotecan in irinotecan-refractory metastatic colorectal cancer. N Engl J Med. 2004;351(4):337-345.

55. Bonner JA, Harari PM, Giralt J, et al. Radiotherapy plus cetuximab for squamous-cell carcinoma of the head and neck. N Engl J Med. 2006; 354(6):567-578.

56. Vermorken JB, Trigo J, Hitt R, et al. Open-label, uncontrolled, multicenter phase II study to evaluate the efficacy and toxicity of cetuximab as a single agent in patients with recurrent and/or metastatic squamous cell carcinoma of the head and neck who failed to respond to platinumbased therapy. J Clin Oncol. 2007;25(16):2171-2177.

57. Goldstein NI, Prewett M, Zuklys K, Rockwell P, Mendelsohn J. Biological efficacy of a chimeric antibody to the epidermal growth factor receptor in a human tumor xenograft model. Clin Cancer Res. 1995;1(11):1311-1318.
58. Li S, Schmitz KR, Jeffrey PD, et al. Structural basis for inhibition of the epidermal growth factor receptor by cetuximab. Cancer Cell. 2005;7(4):301-311.

59. Waksal HW. Role of an anti-epidermal growth factor receptor in treating cancer. Cancer Metastasis Rev. 1999;18(4):427-436.

60. Yarden Y, Ullrich A. Growth factor receptor tyrosine kinases. Annu Rev Biochem. 1988;57:443-478.

61. Masui H, Moroyama T, Mendelsohn J. Mechanism of antitumor activity in mice for anti-epidermal growth factor receptor monoclonal antibodies with different isotypes. Cancer Res. 1986;46(11):5592-5598.

62. Mendelsohn J. The epidermal growth factor receptor as a target for cancer therapy. Endocr Relat Cancer. 2001;8(1):3-9.

63. Yang XD, Jia XC, Corvalan JR, et al. Eradication of established tumors by a fully human monoclonal antibody to the epidermal growth factor receptor without concomitant chemotherapy. Cancer Res. 1999;59(6):1236-1243.

64. Fan Z, Baselga J, Masui H, Mendelsohn J. Antitumor effect of antiepidermal growth factor receptor monoclonal antibodies plus cisdiamminedichloroplatinum on well established A431 cell xenografts. Cancer Res. 1993;53(19):4637-4642.

65. Milas L, Mason K, Hunter N, et al. In vivo enhancement of tumor radioresponse by $\mathrm{C} 225$ antiepidermal growth factor receptor antibody. Clin Cancer Res. 2000;6(2):701-708.

66. Doody JF, Wang Y, Patel SN, et al. Inhibitory activity of cetuximab on epidermal growth factor receptor mutations in non small cell lung cancers. Mol Cancer Ther. 2007;6(10):2642-2651.

67. Sunada H, Magun BE, Mendelsohn J, MacLeod CL. Monoclonal antibody against epidermal growth factor receptor is internalized without stimulating receptor phosphorylation. Proc Natl Acad Sci U S A. 1986;83(11):3825-3829.

68. Baselga J, Pfister D, Cooper MR, et al. Phase I studies of anti-epidermal growth factor receptor chimeric antibody C225 alone and in combination with cisplatin. J Clin Oncol. 2000;18(4):904-914.

69. Thienelt CD, Bunn PA Jr, Hanna N, et al. Multicenter phase I/II study of cetuximab with paclitaxel and carboplatin in untreated patients with stage IV non-small-cell lung cancer. J Clin Oncol. 2005;23(34): 8786-8793.

70. Robert F, Blumenschein G, Herbst RS, et al. Phase I/IIa study of cetuximab with gemcitabine plus carboplatin in patients with chemotherapy-naive advanced non-small-cell lung cancer. J Clin Oncol. 2005;23(36):9089-9096.

71. Rosell R, Robinet G, Szczesna A, et al. Randomized phase II study of cetuximab plus cisplatin/vinorelbine compared with cisplatin/ vinorelbine alone as first-line therapy in EGFR-expressing advanced non-small-cell lung cancer. Ann Oncol. 2008;19(2):362-369.

72. Butts CA, Bodkin D, Middleman EL, et al. Randomized phase II study of gemcitabine plus cisplatin or carboplatin [corrected], with or without cetuximab, as first-line therapy for patients with advanced or metastatic non small-cell lung cancer. J Clin Oncol. 2007;25(36): 5777-5784.

73. Pirker R, Szczesna A, von Pawel J, et al. FLEX: A randomized, multicenter, phase III study of cetuximab in combination with cisplatin/ vinorelbine $(\mathrm{CV})$ versus $\mathrm{CV}$ alone in the first-line treatment of patients with advanced non-small cell lung cancer (NSCLC). J Clin Oncol (Meeting Abstracts). 2008;26(15 suppl):3.

74. Hanna N, Lilenbaum R, Ansari R, et al. Phase II trial of cetuximab in patients with previously treated non-small-cell lung cancer. J Clin Oncol. 2006;24(33):5253-5258.

75. Kim ES, Mauer AM, Fossella FV, et al. A phase II study of Erbitux (IMC-C225), an epidermal growth factor receptor (EGFR) blocking antibody, in combination with docetaxel in chemotherapy refractory/ resistant patients with advanced non-small cell lung cancer (NSCLC). Proc Am Soc Clin Oncol. 2002;21:293a.

76. Hughes S, Liong J, Miah A, et al. A brief report on the safety study of induction chemotherapy followed by synchronous radiotherapy and cetuximab in stage III non-small cell lung cancer (NSCLC): SCRATCH study. J Thorac Oncol. 2008;3(6):648-651. 
77. Franklin WA, Veve R, Hirsch FR, Helfrich BA, Bunn PA, Jr. Epidermal growth factor receptor family in lung cancer and premalignancy. Semin Oncol. 2002;29(1 Suppl 4):3-14.

78. Lynch TJ, Bell DW, Sordella R, et al. Activating mutations in the epidermal growth factor receptor underlying responsiveness of non-small-cell lung cancer to gefitinib. N Engl J Med. 2004;350(21):2129-2139.

79. Kubo A, Nakagawa K, Kashii T, et al. Correlative study of EGFR mutations or protein expressions of EGFR, phosphorylated EGFR, HER2, phosphorylated HER2 and IGFR-1 with gefitinib sensitivity in patients with non-small cell lung cancer: Results of West Japan Thoracic Oncology Group trial (WJTOG0203A). J Thoracic Oncol. 2007; 2:8(Suppl 4):S323.

80. Toyooka S, Takano T, Kosaka T, et al. The impact of EGFR mutation and smoking status on non-smallcell lung cancer patients treated with geftinib. J Thorac Oncol. 2007;2(8 (Suppl 4)):S324.

81. Hirsch FR, Varella-Garcia M, Bunn PA Jr, et al. Molecular predictors of outcome with gefitinib in a phase III placebo-controlled study in advanced non-small-cell lung cancer. $J$ Clin Oncol. 2006;24(31):5034-5042.

82. Hirsch FR, Varella-Garcia M, Cappuzzo F, et al. Combination of EGFR gene copy number and protein expression predicts outcome for advanced non-small-cell lung cancer patients treated with gefitinib. Ann Oncol. 2007;18(4):752-760.

83. Tsao MS, Sakurada A, Cutz JC, et al. Erlotinib in lung cancer - molecular and clinical predictors of outcome. N Engl J Med. 2005;353(2):133-144.

84. Han SW, Kim TY, Hwang PG, et al. Predictive and prognostic impact of epidermal growth factor receptor mutation in non-small-cell lung cancer patients treated with gefitinib. J Clin Oncol. 2005;23(11):2493-2501.

85. Mitsudomi T, Kosaka T, Endoh H, et al. Mutations of the epidermal growth factor receptor gene predict prolonged survival after gefitinib treatment in patients with non-small-cell lung cancer with postoperative recurrence. J Clin Oncol. 2005;23(11):2513-2520.

86. Takano T, Ohe Y, Sakamoto H, et al. Epidermal growth factor receptor gene mutations and increased copy numbers predict gefitinib sensitivity in patients with recurrent non-small-cell lung cancer. J Clin Oncol. 2005;23(28):6829-6837.

87. Hirsch FR, Herbst RS, Olsen C, et al. Increased EGFR gene copy number detected by fluorescent in situ hybridization predicts outcome in non-small-cell lung cancer patients treated with cetuximab and chemotherapy. J Clin Oncol. 2008;26(20):3351-3357.

88. Takano T, Ota S, Hori A, Seki N, Eguchi K. Can epidermal growth factor receptor-fluorescent in situ hybridization predict clinical benefit from cetuximab treatment in patients with non-small-cell lung cancer? J Clin Oncol. 2009;27(3):464-465; author reply 465-467.

89. Eberhard DA, Giaccone G, Johnson BE. Biomarkers of response to epidermal growth factor receptor inhibitors in Non-Small-Cell Lung Cancer Working Group: standardization for use in the clinical trial setting. J Clin Oncol. 2008;26(6):983-994.
90. Varella-Garcia M. Stratification of non-small cell lung cancer patients for therapy with epidermal growth factor receptor inhibitors: the EGFR fluorescence in situ hybridization assay. Diagn Pathol. $2006 ; 1: 19$

91. Goldman JM, Melo JV. Chronic myeloid leukemia - advances in biology and new approaches to treatment. $N$ Engl J Med. 2003; 349(15):1451-1464.

92. Slamon DJ, Godolphin W, Jones LA, et al. Studies of the HER-2/ neu proto-oncogene in human breast and ovarian cancer. Science. 1989;244(4905):707-712.

93. Weinstein IB. Cancer. Addiction to oncogenes - the Achilles heal of cancer. Science. 2002;297(5578):63-64.

94. Benvenuti S, Sartore-Bianchi A, Di Nicolantonio F, et al. Oncogenic activation of the RAS/RAF signaling pathway impairs the response of metastatic colorectal cancers to anti-epidermal growth factor receptor antibody therapies. Cancer Res. 2007;67(6):2643-2648.

95. Lievre A, Bachet JB, Le Corre D, et al. KRAS mutation status is predictive of response to cetuximab therapy in colorectal cancer. Cancer Res. 2006;66(8):3992-3995.

96. Di Fiore F, Blanchard F, Charbonnier F, et al. Clinical relevance of KRAS mutation detection in metastatic colorectal cancer treated by Cetuximab plus chemotherapy. Br J Cancer. 2007;96(8):1166-1169.

97. Goncalves A, Esteyries S, Taylor-Smedra B, et al. A polymorphism of EGFR extracellular domain is associated with progression freesurvival in metastatic colorectal cancer patients receiving cetuximabbased treatment. BMC Cancer. 2008;8:169.

98. Barber TD, Vogelstein B, Kinzler KW, Velculescu VE. Somatic mutations of EGFR in colorectal cancers and glioblastomas. $N$ Engl J Med. 2004;351(27):2883.

99. Chung KY, Shia J, Kemeny NE, et al. Cetuximab shows activity in colorectal cancer patients with tumors that do not express the epidermal growth factor receptor by immunohistochemistry. J Clin Oncol. 2005;23(9):1803-1810.

100. Moroni M, Veronese S, Benvenuti S, et al. Gene copy number for epidermal growth factor receptor (EGFR) and clinical response to antiEGFR treatment in colorectal cancer: a cohort study. Lancet Oncol. 2005;6(5):279-286.

101. Eberhard DA, Johnson BE, Amler LC, et al. Mutations in the epidermal growth factor receptor and in KRAS are predictive and prognostic indicators in patients with non-small-cell lung cancer treated with chemotherapy alone and in combination with erlotinib. J Clin Oncol. 2005;23(25):5900-5909.

102. Zhu CQ, da Cunha Santos G, Ding K, et al. Role of KRAS and EGFR as biomarkers of response to erlotinib in National Cancer Institute of Canada Clinical Trials Group Study BR.21. J Clin Oncol. 2008;26(26):4268-4275.

\section{Publish your work in this journal}

Biologics: Targets \& Therapy is an international, peer-reviewed journal focusing on the patho-physiological rationale for and clinical application of Biologic agents in the management of autoimmune diseases, cancers or other pathologies where a molecular target can be identified. This journal is indexed on PubMed Central, CAS,
Dovepress

EMBase, Scopus and the Elsevier Bibliographic databases. The manuscript management system is completely online and includes a very quick and fair peer-review system, which is all easy to use. Visit http://www.dovepress.com/testimonials.php to read real quotes from published authors. 